\title{
Development of skills and critical thinking in junior high school students towards quality basic education in Ghana
}

Larbi, Frank Okai $\$

Beijing Normal University, China (lof45@hotmail.com)

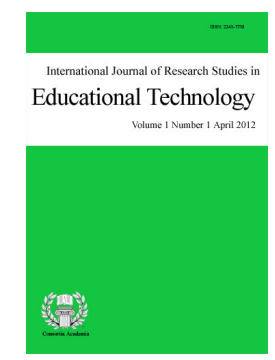

Accepted: 13 July 2017

ISSN: $2243-7738$ Online ISSN: 2243-7746

OPEN ACCESS

\section{Abstract}

Critical thinking and skill development are elements that cannot be overlooked in basic education. This study aims to discover public basic education along with other external factors that influence the development of skills and critical thinking, which have influence on employability, productivity and international competitiveness. It focuses on four major areas that influence skill development and critical thinking in basic school students: the curriculum, teaching methods, teacher/student relationships and extra-curricular activities. This paper focuses on the impediments to the development of students' critical thinking and skills, and methods and theories to be applied in the classroom to develop students' critical thinking. In this study, I analyzed the junior high school (JHS) curriculum to identify the kind of skills it intends to develop and observed teachers' pedagogy in the classroom. This study is a qualitative study, which adopted interview, observation and document analysis to collect and analyze data. The population considered in this research includes headmasters, teachers and students, and parents from three public schools located in the Ashanti region of Ghana. The findings of this study will allow the creation of effective pedagogy aimed at learning with practical approach; learning that includes dynamic roles of the classroom, teaching strategies and teaching and learning materials. Comprehensive recommendations have been provided for educational policy makers, educational directors, headmasters/mistress, and parents to cause a paradigm shift in the superannuated educational system in Ghana. Again, recommendations have been proposed to researchers on how to develop this research by focusing on the preeminence of utilizing technology and technological tools in the schools' curriculum to enhance students' critical thinking and skills.

Keywords: critical thinking; engaged pedagogy; curriculum; basic education 


\section{Development of skills and critical thinking in junior high school students towards quality basic education in Ghana}

\section{Introduction}

Education promotes human development and contributes to nation building. It is an important tool for the optimum development of a nation's human or manpower resources, which contributes largely to a nation's total economic growth. Correspondingly, emerging economies pay attention to education and invest in education for the production of a skilled labor force. Educational planning, for this reason, is a vital part of the total economic and social planning that a nation undertakes periodically in order to improve the well-being and living conditions of its people. Interestingly, each level of education yields a different effect on economic development; primary and secondary educations have a greater effect on basic worker productivity while higher education has a greater effect on technological innovation (Garcia, Gunawan, \& Jreij, 2013, p. 4). The curriculum is an essential component of any educational process. It sets the parameters and gives directions to the educational process. It addresses questions such as what students should learn and be able to do, why, how, and how well.

The junior high school curriculum is loaded with much information, many subjects to be taught within a limited period, therefore, teaching and learning become abstract, which does not enhance practical approach to involve students in teaching and learning process to increase their abilities to think critically, solve problems, and develop their skills and potentials. As a result, teaching becomes teacher centered and students become passive learners, which is termed as banking system of education (Freire, 1998). On the other hand, there is a lack of technological equipment such as computers, projectors, and internet accessibilities in most of the public schools in Ghana, which makes it problematic to integrate information communication technology (ICT) in teaching and learning process. ICT is capable of enhancing students' knowledge by engaging in discussions and exploring information technologically whiles they used experiences gained to help solve societal problems.

Discovering the factors that thwart the development of skills and critical thinking will assist the Ghanaian government in establishing educational policies, which aims to modify the curriculum and pedagogy to be geared towards student-centered and problem-posing type of education rather than teacher centered. These findings will allow for the creation of effective pedagogy aimed at learning with practical approach; learning that includes dynamic roles of the classroom, teaching strategies and teaching and learning materials, the role of family and home environment and the role of the community. Discussions and analyses on the significance of skill development in students and economic development will prove insightful and relevant to economic and education issues in Ghana.

This study aims to discover public primary education along with other external factors that influence the development of skills and critical thinking, which has an influence on employability, productivity, and international competitiveness. It focuses on four major areas that influence skill development and critical thinking in basic school students; the curriculum, teaching methods, teacher/student relationships and extra-curricular activities. After in-depth analysis and investigation of the four major areas mentioned above, I will make a comprehensive recommendation for educational policy makers, educational directors, educationist, and headmasters/mistress to cause a significant change in the educational system in Ghana.

This research will utilize the qualitative method, which will specifically make use of the following research methods to collect, analyze, observe, reflect, act and evaluate the research question to make a decisive plan about the existing phenomenon. The research methods to be considered are observation, interview, and document analysis. During this study, I will observe how JHS teachers teach their students, that is the teaching methods and techniques they apply to teach, how they respond to students' questions, in what ways do students participate in the teaching and learning process, and all activities that transpire in the classroom will be observed 
as well.

Moreover, I will apply interview to collect data on teachers' opinion on the choice of teaching methods they utilize in class, their suggestion on amending the curriculum towards development of students' critical thinking, students' readiness to be engaged in teaching and learning process, the relationship that exist between them and their students, and how they utilize teaching and learning materials in the classroom. Again, I will interview headmasters to investigate the availability of teaching and learning materials for teachers to utilize to practically demonstrate what they teach, also, whether teachers are supervised regularly to ensure they engage students during the teaching and learning process, and how possible to amend the curriculum to be geared towards skill development and critical thinking. Students will also be interviewed as well to find out how they are involved or contribute during teaching and learning process. I will investigate whether students have the agency to interact and critically air their views on matters in the classroom. Finally, I will employ document analysis to analyze the content of the JHS curriculum to identify its strengths and weaknesses in terms of the development of skills and critical thinking.

\section{Critical thinking}

Barak and Dori (2009) view critical thinking as a skill that develops one's conscientiousness and enhances his/her thinking abilities, to "reflect and reasonable think to focus on deciding what to believe or do" (Ennis, 1985 , p. 45). It entails coherency and reflective thought to make a person more responsible in his believes and actions. Phiters and Soden (2000) stated that critical thinking is the ability to evaluate how valid or reliable assertion by others are, and also the different source of information that is existing. Coronado (2011, p. 8) added that "critical thinking focuses on revealing poor reasoning and confronting the power structures that are in control of information, to ensure that the users are not misled". Bailin (2002) defines critical thinking as good thinking that is of a particular value, which is meant towards adequacy and accuracy of the standardized phenomenon. Facione (1990) also added that critical thinking is exhibiting qualities such as critical enquiry mindset, non-judgmental attitude, flexibility, neutrality, been well-informed, understands diverse viewpoints. Critical thinking requires awareness and deep strategic intellectual thinking to unleash creativity. Paul and Elder (2006 p. 35) noted that "critical thinking without creativity reduces to mere skepticism and negativity, and creativity without critical thought reduces to mere novelty", in practice, the two concepts are connected to each other and developed in par. Paul and Elder (2006) pointed out that both creative and critical thinking ought to be integrated during classroom instruction.

Paul (1992) argues that traditional classroom instruction does not develop higher-order thinking skills like critical thinking. Bailin, Case, Coombs, and Daniels (1999) added that classroom instructions to develop critical thinking at the primary grade levels can include the following; teaching students to value reason and truth; respect others during discussion; be open-minded; be willing to see things from another's perspective; perceive the difference between definitions and empirical statements; use cognitive strategies, such as asking for examples when something is unclear; and use principles of critical thinking, such as considering alternatives before making a decision. Facione (1990, p. 27) also argued that "from early childhood, people should be taught, for example, to reason, to seek relevant facts, to consider options, and to understand the views of others". Many researchers about critical thinking have maintained the fact that critical thinking can be taught in the classroom. Thus, open-ended problem types and problem posing questions are more appropriate for assessing critical thinking than traditional multiple-choice questions. $\mathrm{Ku}$ (2009) argues that available empirical evidence suggests that open-ended questions better capture the construct of critical thinking because they are more sensitive to the dispositional aspects of critical thinking than are multiple-choice questions. Critical thinking cannot be relegated to the background from the primary level through to the tertiary level due to its importance to nation building. In this epoch of globalization, students must be taught to cope with the developmental trend and built their mental ability to intellectually compete internationally.

Skills Shortage Dilemma - An eroding education system from the basic school level to the tertiary level in 
Ghana is contributing the skills shortage dilemma every year. Currently, the demand for specific occupational skills, soft skills and basic literacy and numeracy skills exceed the supply of these skills (Fazio \& Pinder, 2012). As a result, Ghana's economy is currently faced with many challenges, like high unemployment and brain drain, partly stemming from the lack of employable skills in the labour market. The skills shortage is undermining Ghana's opportunities for economic development. Currently, the Ghanaian government schools, specifically those in low-income communities and the rural areas are failing because children are not developing skills relevant for self-development and the country's economic growth.

Junior high school - The junior high school (JHS) is a period of three years that is between 12 to 15 years old. JHS level is considered due to its sensitive part of the educational ladder, it is transition from basic school to senior high school. Students are expected to identify their skills and interest in their academic pursuit to specialize in the senior high school and above. The JHS curriculum is grouped into two parts, the compulsory subjects and the optional subjects. The subjects include English Language, Mathematics, Integrated Science, Social Studies, Basic Design Technology (BDT), Ghanaian language, Information Communication Technology (ICT) Religious and Moral Education (RME), French. All the above subjects are meant to develop students' skills and creativity, however, the reality is opposite. At the end of this level of education, one is required to sit for the Basic Education Certificate Examination (BECE) to ensure selection into the Senior High School/Technical Institutions.

Curriculum aspiration - At the basic school level, the teaching of mathematics emphasizes mathematical knowledge and skills that should help the young person to develop competence in basic numeracy to function effectively in society. The skills taught include the ability to use numbers competently, read and interpret numeral data, reason logically, solve problems involving calculations and mathematical reasoning, as well as communicate effectively with other people using accurate mathematical data and interpretations. In addition, pupils are required to develop interest in the use of mathematics and the ability to conduct investigations using mathematical ideas. It is the acquisition of these qualities and the important quality of functional mathematics that education in Ghana aims to emphasize in the teaching and learning of mathematics in the school system (CRDD, 2007a).

It is expected that scientific experiences in school will cultivate in pupils an interest and love for science that will urge some of them to seek further studies in science as preparation for careers in science (Ampiah, 2010). Some of the positive attitudes and values pupils are expected to develop include the spirit of curiosity, creativity and critical thinking; skills, habits of mind and attitudes necessary for scientific inquiry; the spirit of curiosity for investigating and understanding their environment (Ampiah, 2010); communicate scientific ideas effectively; use scientific concepts for explaining their own lives and the world around them. For successful study of Science at the basic school level, the curriculum requires that pupils should have good observational skills, mathematical skills and communication skills (CRDD, 2007b).

As the official language, English is the language of government and administration. It is the language of commerce, the learned professions and the media. As an international language, it is the most widely used on the internet and in most parts of the world. In Ghana, English is the medium of instruction from Primary 4 in the school system. It is for these and other reasons that English Language is a major subject of study in Ghanaian schools. Teaching and learning English language in basic schools is aimed to develop in pupils, basic language skills such as listening, speaking, reading and writing. English proficiency acquired will help pupils to study other subjects as well as in the study of English at higher levels (CRDD, 2007c).

\section{Impediments to skills development and critical thinking in basic schools in Ghana}

Inappropriate teaching and learning methods - One of the key hindrances that thwart the development of students' innovation and critical thinking is the process by which teaching and learning are carried out. Many teachers adapt teacher-centered method of teaching, characterized by banking system of education, which 
Development of skills and critical thinking in high school students towards quality basic education in Ghana

increases passivity of learners (Freire, 1970). In this situation, teaching and learning are not based on problem-posed education; therefore, learners do not enhance their skills and creativity through practice and involvement to solving problems in collaborative project works and assignments. Students learn new lessons by rote. There is tension and nervousness amongst students because they memorize ideas and concepts as preparedness towards terminal examinations and class test, therefore, they forget everything after writing examination. The nature of teaching and learning methods some teachers adopt in the classroom, impose fear and anxiety on students, which have negative influence on their self-realization and development. Unfortunately, many students are not able to apply knowledge gained in school for self and societal development; as a result, many institutions lack skilled personnel needed to carry out several projects.

Teacher-student relationship - The authority teachers assume in class has led to unfavorable relationship between them and their students. Freire (1970) asserted that in the banking system of education, the teacher talks and the students listen meekly; the teacher chooses and enforces his choice, and students comply. Again, the teacher confuses the authority of knowledge with his own professional authority, which he sets in opposition to the freedom of the students; and the teacher is the Subject of the learning process, while the pupils are mere objects. It is argued that the above assertion constitute to marred and distorted relationships between students and teachers. Students are unable to confide in their teachers, and teachers do not sympathetically and maternally respond to the needs of their students. In situations like this, teachers fail to hold relevant guidance and counseling to build up students, therefore, anemic relationship between teachers and students does not encourage physiological developments of students.

Lack of teaching and learning materials - Due to unavailability of teaching and learning materials (TMLs), teachers tend to abstractly carry out lessons. Students are not exposed to real objects or convincible evidence to completely comprehend ideas expressed in lessons taught. Seeing, touching, feeling and tasting are evidence of reality that will unleash students' criticalness on relevant matters in their societies. The reason for lack of teaching and learning materials in many public schools is attributed to inadequate finance released to schools for day-to-day administration. In subjects like Information Communication Technology (ICT), most schools do not have computers and internet facilities to enrich students and keep them abreast with technological advancement to influence and develop their critical mindset. This situation has caused many students to be technophobic.

Limited time allocated for extra-curricular activities - Extra-curricular activities such as quiz and debate competitions, sports, cultural activities, and other relevant activities capable for developing students' creativity and enhancing cooperation between teachers and students have been overlooked in many schools. Less is done to enhance their psychomotor skills. This has led to difficulties of identification of talents and skills in students. It is proposed that schools should have ample time allocated for well-planned extra-curricular activities under proper supervision to achieve its purpose of enriching students' creativity and skills, and enhancing student-teacher and student-student relationship.

Language of instruction - Students communicate and comprehend ideas better in their mother tongue (L1), however, the use of English as a language of instruction impedes students' understanding and their ability to make critical enquiries and contributions to matters arising in and out of the classroom. Some scholars argue that the language of instruction should be a mixture of English language and students' L1 to enable them make a substantive contribution, whiles it also help to enhance their understanding and comprehensively broaden their knowledge in the subject area. However, it is a challenge to adopt students' L1 as a language of instruction because of unavailability of textbooks and TLMs in that language.

Poor supervision of teachers - In many public schools in Ghana, headmasters and circuit supervisors do not supervise teachers regularly in the classroom to inspect and guide them on the use of appropriate teaching methods, the use of TLMs and proper engagement of students in the teaching and learning process. Poor supervision of teachers has led to mismanagement of classroom, mishandling of students by the use of 
punishment to intimidate them, and flaws in teaching. In addition, class exercises and assignments giving to students do not challenge them to unleash their research skills, and improve their ways of critical enquiries. Students are punished for low scores in class exercises and test, which intimidate them and diminish their interest to enthusiastically continue their education. Teachers should rather encourage and assist students with learning difficulties one-on-one instead of using punishment to inculcate fears in them, which will deter them from working diligently to augment their skills and creativity. Headmasters and circuit supervisors should not only be concerned with checking teachers' attendance and lesson notes, rather, much attention should be paid on teaching and learning in the classrooms to encourage teachers to be skillful and innovative to carry out lessons to help thrive students' creativity and skills.

\section{Constructionism and Engaged Pedagogy as theories to enhance students' critical thinking and}

\section{engagement in the classroom}

In this section, concepts are formulated to explain, predict, and understand phenomena of the ways students are taught and nurtured in JHS. First, "Constructionism is of the view that all knowledge, and therefore all meaningful reality as such, is contingent upon human practices, being constructed in and out of interaction between human beings and their world, and developed and transmitted within an essentially social context" (Crotty, 1998, p. 42). It refers to how people in a society construct meaning through social interaction with others. In this phenomenon, children learn through participation and doing to create their own experience. In order to investigate how knowledge is constructed and understood in basic schools it is essential to find out the pedagogical approach adopted by teachers to interact with students and guide them to also interact amongst themselves to construct meanings of reality. Social constructionism focuses on daily interactions between people in a society and how they use language to construct reality, (Tom, 2012). Language is indispensable in the process of constructing reality; therefore, students should be able to express themselves well in the language of instruction to create conducive atmosphere to interact with each other. Unlike constructivism, whereby meaning is constructed based on individual's cognitive, constructionism deals with people-to-people constructing of meaning of reality. Hence, the idea of constructionism will help comprehend how the curriculum can be designed to promote interactional opportunity for students to construct meanings of reality in their societies. In addition, the epistemological conception of social constructionism will enlighten teachers on how to create a classroom that gives more room to engage students in teaching and learning process.

Second, the theory I would propose to be adopted by teachers in the classroom is engaged pedagogy. According to bell hooks (1994), engaged pedagogy is an engagement of mind, body and spirit leading to a critical consciousness. Engage pedagogy opposes banking system of education whereby the teacher has all the power in the classroom and learners are considered as passive learners (Freire, 1970). According to Freire, knowledge is deposited in the minds of students; they do not critically reflect or argue on what is taught. This type of education is common in many public schools in a Ghana. With the practice of engaged pedagogy, teachers learn from the experiences and ideas expressed by students. Dialogue is promoted between teachers and students, which enable students to construct meanings to reality in the society. "Engaged pedagogy assumes that every student has a valuable contribution to make to the learning process", (hooks, 2010, p. 21). According the above assertion by bell hooks, when teachers teach based on this theory, students will take active part in the learning process to enhance their critical thinking. Engaged pedagogy helps to provide impetus on the need to enable teachers in Ghanaian basic schools to adopt or improve their pedagogies to create a classroom in which students will have the agency to interact with each other including the teacher to construct meaningful ideas.

The framework of the engaged pedagogy above involves the processes to develop students' critical thinking and skills. Students should be actively engaged in the learning process through problem-based learning in schools to enable them to critically reflect on social phenomenon. Cooperative learning should be encourage in the classroom to enhance students' engagement in the teaching process. Thayer-Bacon (2000) argues that students' relationship with others in the classroom during the learning process is important for critical thinking 
and skill development. Bailin et al. (1999), also added that critical thinking involves the ability to respond constructively to others during group discussion, by encouraging and respecting the contributions of others as a result of active engagement in the classroom. As a result of critical reflection, critical thinking will be enhanced to enable students to make a substantive contribution to problem solving through skill development.

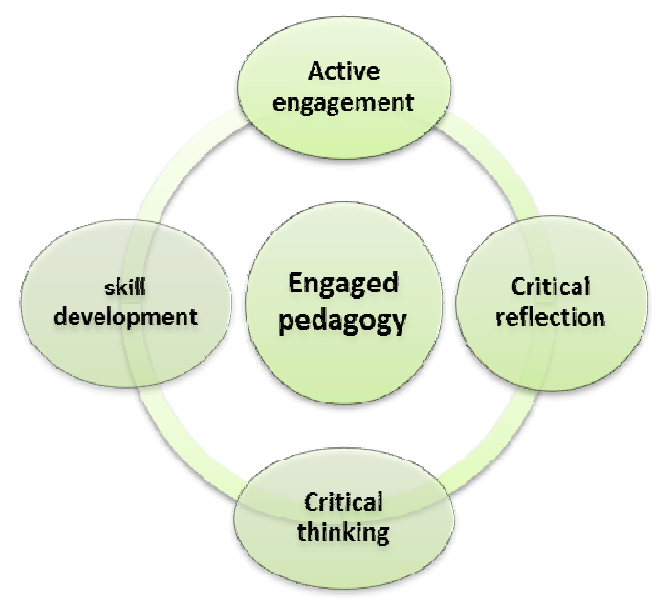

Figure 1. Cyclical presentation of the process involved in engage pedagogy to develop critical thinking

\section{Conclusion and recommendations}

This study argues that basic education is the foundation for skill development thereby teaching of critical thinking should be enhanced. However, there are hidden factors that affect skill development, whether directly or indirectly. This leads to the study's ultimate argument, basic education in the context of curriculum and instruction, is not the only facilitating factor in the development of skills. While basic education is a primary determinant for the development of cognitive and non-cognitive skills in children, there are other significant factors that are ignored during education reform dialogues; thus, they are the home and the community.

As Ghanaian students on average spend six hours in school per day, the remaining time is spent at home and in the community. The time that is spent at home and in the community, can either facilitate or impede skill development. In summary, the following points highlighted below should be considered in developing student' skills; firstly, primary school must go beyond the current curriculum operating in the school system today, which focuses on various subjects from math, reading, and writing to family life, religion, arts, music, and social studies. It must also equip students with trades, crafts, the arts and music programs in the school to help students with discovering their path in life and how to better work towards reaching their goal. Curriculums, teaching methods and strategies have significant effects on students' skill development and critical thinking. Through appropriate teaching methods, styles and strategies, teachers can develop students' mental faculty and domain through teaching and assessment. As Ku (2009, p. 75) argues, "teachers should adopt different assessment methods, such as exercises that allow students to self-construct answers, assignments that facilitate the practice of strategic use of thinking skills in everyday contexts, and when adopting multiple-choice exercises, follow-up questions should be given to probe students' underlying reasoning". Educators may have a perfect curriculum detailed with all the needs of students' critical thinking and skill development, but if teachers do not use the correct methods of teaching, students' skill development and critical thinking will be unachievable. Per the affective domain, which is enhanced by teacher and student relationship, when teachers exude a relationship that is loving, friendly and welcoming with their students, the students will feel emotionally relaxed with their teachers, which will enable them to disclose any challenges they encounter that affect their emotions. In addition, they will feel free to ask questions to boost up their learning habits. Contrarily, if teachers instill fear in their students it will impede the learning process in the classroom, as students will be in fear disengage them in contributing to the lessons taught. Per the psychomotor domain, which deals with the physical activities or extracurricular activities, educators must include extracurricular activities that will help to develop student's 
creativity, talents and confidence outside of the classroom. Such activities should include vocational studies, sports, creative arts, professional training via field trips, motivational and self-esteem activities.

Secondly, a child's environment outside of the class is significant to skill development and critical thinking. Parents, siblings, relatives and family friends have a major role in a child's development. As a matter of fact, they can either facilitate or impede development. There are many factors that should be considered from the home, some include, learning resources available in the home, socio-economic status of parents/family, education of parents/family, and interaction with parents/family with the child. Thus, I suggest that the home is a determinant of skill development facilitating or impeding learning.

Thirdly, the community or society has a significant role to play in skill development. Society is very powerful in shaping normative values of people. If society should recognize that education is important to economic advantages like businesses opportunities and, employment, while simultaneously addressing social issues like the reduction of crime and poverty, it must engage itself to improve skill development in students. Programs engineered specifically for students development should include; summer programs, afterschool clubs, reading programs in public libraries, mentorship programs, entrepreneurial programs, motivational lecturers, internships, and explorations, these are several examples of activities that Non-Governmental Organizations (NGOs), Churches, private organizations, and individuals can engage while students should be mandate to participate. Indeed, children spend time at their friend's house in their neighborhood and on the play ground, consequently, peer pressure, and expectations from community friends, recreational time and programs also develop skills in children whether positive or negative.

In conclusion, skills students develop in early stage in life have a positive impact on nation building, therefore, educationist and policy makers should revise the content of the curriculum, and set up programs to train teachers to be more creative and skillful in the teaching and learning process. There is high level of unemployment in Ghana due to the dilemma of skills shortage; as a result, the public education system is in need of reform. First, basic schools must be more effective, having the ability to accomplish what it has set out to achieve. The system at the JHS level must not only produce literate graduates but also inspire the JHS graduates to achieve greater accomplishments having identified their careers and passions. The responsibility cannot be placed on formal education solely. Parents, relatives and caregivers must take the responsibility and contribute to their children's development of skills by assisting them with homework, motivating them to study and work hard in the classroom. Children take their support from home to the classroom and it influences their behavior. Some rare children perform exceptionally without any support. Those rare children have a different pattern of learning and their abilities can be seen as a gift. For many other children however, support and motivation is highly instrumental in facilitating learning and skill development. When Ghanaian students are deterred from their dreams and passions often times birthed at the basic School level, the labor market misses that skilled labor.

The advancement of technology and the competitive nature of the technological market have led to reduction of prices of some technological tools in Ghana such as mobile phones, tablets, and personal computers. Therefore, I recommend that researchers and educationist in Ghana and other developing countries should focus and investigate how to profitably utilize technology in and after classroom instructions to engage students in critical discussions, online collaborative studies, and other useful educational programs online to enable students respond critically to phenomenon whiles they learn from their peers and other substantive platforms to enhance their skills and critical thinking.

Acknowledgement: I sincerely express my profound gratitude to all those who tender heartedly assisted me to successfully complete this study. First, I thank my supervisor, Dr. Liu Qiang for his advice, encouragement and guidance towards research and academic writing skills to enhance my research potency. I am also grateful to my friend "Silas Bonney", for assisting me to collate data from all participants in Ghana. He helped with the realization of this research through diligence and commitment. I also express gratitude to all participants 
Development of skills and critical thinking in high school students towards quality basic education in Ghana

(headmasters, teachers, students and parents) who made information available for analysis in this study. Finally, thanks to all my friends and love ones who encouraged and supported me emotionally and intellectually to make this study a success. I presented this paper in the "World Congress of Comparative Education Societies (WCCES)" conference in August, 2016 hosted by Beijing Normal University.

\section{References}

Ampiah, J. G. (2008). An investigation of provision of quality basic education in Ghana: A case study of selected schools in the Central Region. Journal of International Cooperation, 11(3), 19-37.

Bailin, S., Case, R., Coombs, J. R., \& Daniels, L. B. (1999). Conceptualizing critical thinking. Journal of Curriculum Studies, 31(3), 285-302. https://doi.org/10.1080/002202799183133

Barak, M., \& Dori, Y.J. (2009). Enhancing higher order thinking skills among in-service science teachers via embedded assessment. Journal of Science Teacher Education, 20, 459-474. https://doi.org/10.1007/s10972-009-9141-z

Coronado, G. (2011). Web-based-research as critical pedagogy: A reflection on its application to undergraduate management education. Journal of University Teaching \& Learning Practice, 8, 1-15.

CRDD (2007a). Teaching syllabus for integrated science (Primary 4-6). Accra: CRDD. Retrieved from https://mingycomputersgh.files.wordpress.com/2013/01/integrated-science-syllabus-primary-4-6.pdf

CRDD (2007b). Teaching syllabus for mathematics (Primary 1-6). Accra: CRDD. Retrieved from https://mingycomputersgh.files.wordpress.com/2013/01/integrated-science-syllabus-primary-4-6.pdf

CRDD (2007c). Teaching syllabus for English language (Primary 1-3). Accra: CRDD. Retrieved from https://mingycomputersgh.files.wordpress.com/2013/01/integrated-science-syllabus-primary-4-6.pdf

Crotty, M. (1998). The foundations of social research: meaning and perspective in the research. Sage Publication.

Facione, P. A. (1990). Critical thinking: A statement of expert consensus for purposes of educational assessment and instruction. Millbrae, CA: The California Academic Press.

Fazio, Maria, V., (2012). In pursuit of employable skills: understanding employers' demands: analysis of the Bahamas' 2012 wages \& productivity survey. Retrieved from https://publications.iadb.org/bitstream/handle/11319/6686/In-Pursuit-of-Employable-Skills Understanding-Employers-Demands.pdf

Freire, P. (1998). Chapter 1: Pedagogy of the oppressed. In P. Freire (Ed.), Pedagogy of the oppressed (pp. 43-70). New York, NY: Continuum.

Hall, J. A., \& Hall, E. G. (2010). An intellectual biography. NY: Verso.

Hooks, b (2010). Bell Hooks the teaching trilogy. NY: Routledge.

Julia, G., Devita, G., \& Vennessa, J. (2013). The influence of education on economic development (pp. 12-16). Retrieved from https://oaktrust.library.tamu.edu/bitstream/handle/1969.1/148898/GARCIA-THESIS2013.pdf?sequence $=1$

Ku, K. Y. (2009). Assessing students' critical thinking performance: Urging for measurements using multi-response format. Thinking Skills and Creativity, 4, 70-76. https://doi.org/10.1016/j.tsc.2009.02.001

Ministry of Education. (July, 2013). Education sector performance report. Ghana: Ministry of Education. Papert, S. A. (1999). Mindstorms: Children, computers, and powerful ideas (2nd ed.) New York: Basic books.

Paul, R. W. (1992). Critical thinking: What, why, and how? New Directions for Community Colleges, 77, 3-24. https://doi.org/10.1002/cc.36819927703

Paul, R. W., \& Elder, L. (2006). Critical thinking: The nature of critical and creative thought. Journal of Developmental Education, 30(2), 34-35.

Thayer-Bacon, B. J. (2000). Transforming critical thinking: Thinking constructively. New York, NY: Teachers College Press.

Tom, A. (2012). What is social constructionism? Grounded Theory Review, 11(1). Retrieved from 
Larbi, F. O.

http://groundedtheoryreview.com/2012/06/01/what-is-social-constructionism/ 